\title{
Cellular and molecular aspects of adult brain development in honeybee castes (Apis mellifera L.)
}

\author{
Aline Vomero ${ }^{1 *}$, Heloisa Gianelli ${ }^{1}$, Marcio T Oliveira', Maíra B Lima', Pedro HZ Vitoria', Paulo E Alvarenga', \\ Lívia MR Moda', Joseana Vieira', Ana Bomtorin², Zilá LP Simões², Angel Roberto Barchuk'
}

From 5th Congress of the Brazilian Biotechnology Society (SBBIOTEC)

Florianópolis, Brazil. 10-14 November 2013

\section{Background}

The adult honey bee brain exhibits a complex architecture composed by millions of neurons, glial cells and their respective tracts which form structures known as neuropils. They are organized to produce the optic lobe, antennal lobe, central complex and mushroom bodies. Learning and memory-related skills that honeybee workers use for navigation, foraging, nestmate recognition, and other activities are believed to be associated with the mushroom bodies, which are more developed in the adult members of the worker caste. During larval period, however, the differential feeding offered to prospective queens promotes faster brain development and higher expression of several neurogenic genes (ataxin-2, cryptocephal, dachshund, Eph Receptor, fax, shot, krüppel homolog-1 and tetraspanin 5D) [1]. It seems that in some point during pupation, there happens a shift in this trend. In fact, queen's brain experiences extensive cell death events, but worker's brain is favored by higher rates of cell proliferation, resulting in caste specific brains [2].

\section{Methods}

A. mellifera pupae were collected from colonies (africanized hybrids) at the Experimental Apiary of the Federal Institute of Muzambinho (IFSULDEMINAS) at Muzambinho, Minas Gerais State, Brazil. The developmental stages were classified according to the criteria proposed by Michelette and Soares [3] and Rembold et al[4]. To investigate whether differences could be detected in brain development in the context of caste differentiation we performed neuroanatomical studies of whole mount

'Laboratory of Integrative Animal Biology, Federal University of Alfenas, MG, Brazil

Full list of author information is available at the end of the article preparations of queens and workers pupal brains using actin phalloidin/rhodamin to visualize axons, and DAPI to visualize nuclei. In addition, we used genome-wide expression analyses and normalized transcript expression experiments using RT-qPCR for monitoring specific genes during pupal stages.

\section{Results and conclusions}

Our morphological results showed that during early pupal stages there are no obvious differences between castes brain development. However, late worker pupae exhibit larger calyces, fundamental parts of mushroom bodies, when compared with queens. Gene expression analyses revealed that the transcription profiles in brains of queens and workers (except for $k r-h 1$ ) show an opposite pattern to that observed during larval development, with workers' brain with higher levels of gene transcription (e.g., mesencephalic astrocyte derived neurotrophic factor, minibrain, signal peptide peptidase, and tumbleweed, all associated to neurogenic events or cell death prevention). This indicates that the respective protein products are responsible for the differential development of adult brains between honeybee castes. Particularly, the expression patterns of the neurogenic genes $a t x-2$ and fax and the "anti-cell death" gene signal peptide peptidase help explain the observed inversion of the neuroblasts area in queens and workers' brain, which, during larval period favors queens (very likely due to the differential feeding), and during pupal development and in adults, favors workers.

\section{Acknowledgements}

We thank Sávio Dutra and Rubens Castro for technical assistance in the experimental apiary in Muzambinho. 


\section{Authors' details}

'Laboratory of Integrative Animal Biology, Federal University of Alfenas, MG, Brazil. ${ }^{2}$ Laboratory of Developmental Biology of Honeybees, São Paulo State University, São Paulo, SP, Brazil.

Published: 1 October 2014

\section{References}

1. Moda LM, Vieira J, Freire ACG, Bonatti V, Bomtorin AD, Barchuk AR, Simões ZLP: Nutritionally driven differential gene expression leads to heterochronic brain development in honeybee castes. PLoSOne e64815.

2. Malun D: Early development of mushroom bodies in the brain of the honeybee Apis mellifera as revealed by BrdU incorporation and ablation experiments. Learning \& Memory 1998, 5(1-2):90-101.

3. Michelette ERD, Soares AEE: Characterization of preimaginal developmental stages in africanized honey-bee workers (Apis-mellifera L). Apidologie 1993, 24(4):431-440.

4. Rembold H, Kremer JP, Ulrich GM: Characterization of post-embryonic developmental stages of the female castes of the honey bee, Apis mellifera L. Apidologie 1980, 11(1):29-38.

doi:10.1186/1753-6561-8-S4-P159

Cite this article as: Vomero et al: Cellular and molecular aspects of adult brain development in honeybee castes (Apis mellifera L.). BMC Proceedings 2014 8(Suppl 4):P159.

\section{Submit your next manuscript to BioMed Central} and take full advantage of:

- Convenient online submission

- Thorough peer review

- No space constraints or color figure charges

- Immediate publication on acceptance

- Inclusion in PubMed, CAS, Scopus and Google Scholar

- Research which is freely available for redistribution

Submit your manuscript at www.biomedcentral.com/submit 